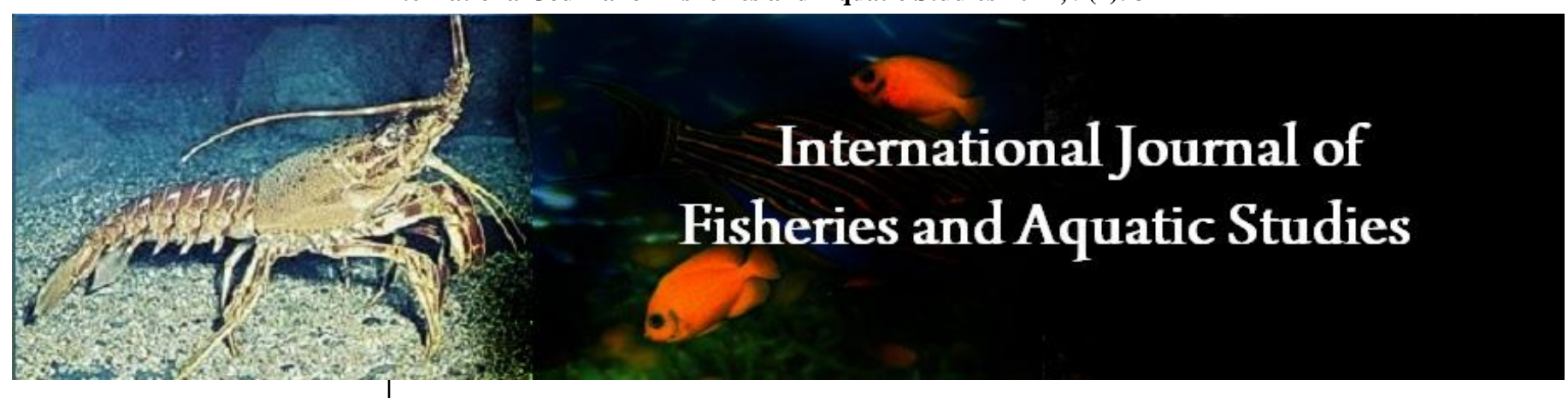

E-ISSN: 2347-5129

P-ISSN: 2394-0506

(ICV-Poland) Impact Value: 5.62

(GIF) Impact Factor: 0.549

IJFAS 2021; 9(1): 34-41

(C) 2021 IJFAS

www.fisheriesjournal.com

Received: 09-11-2020

Accepted: 16-12-2020

Abdulhakim Hussen Hebano

Batu Fish and Other Aquatic

Life Research Center, East Shoa

Zone, Batu, Ethiopia
Corresponding Author:

Abdulhakim Hussen Hebano

Batu Fish and Other Aquatic

Life Research Center, East Shoa

Zone, Batu, Ethiopia

\section{Analysis of factors affecting farmers' participation in fish production in Lake Langano, Ethiopia}

\author{
Abdulhakim Hussen Hebano
}

DOI: $\underline{\text { https://doi.org/10.22271/fish.2021.v9.i1a.2385 }}$

\begin{abstract}
Fishery development is considered as a potential area to enhance income of smallholder farmers in developing countries. In Ethiopia fishing practiced in most freshwater bodies which is a potential strategy for enhancing food security, employment and provide as source of income. Despite the economic importance of fishing at the local level, farm households have paid little attention to the fish production in the study area. Thus, this study was proposed to analyze determinants of farmer's participation decision on fishing in Langano Lake. The study used the cross-sectional survey to collect primary data from 167 same respondents and mixed research approach. Descriptive statistics, inferential statistics and binary probit model were used to analyze the primary data. The result of analysis indicated that farmer's' participation in fish production is significantly determined by various demographic, institutional, social, economic and biophysical factors. To solve the problems and improve the farmer's participation in fish production, the government and nongovernment organizations, specially district livestock and fishery dev elopment office should attempt to hamper factors that hind-er participation in fish production and enhanc e factors that initiates participation in the fishing practice identified in the study.
\end{abstract}

Keywords: Factors, probit model, fish production, participation, Lake Langano

\section{Introduction}

\subsection{Background and Justification}

Fishery production is the basic sector for reducing poverty and it could be well-thought-out as a potential scheme because it helps to expand house hold income directly and indirectly ${ }^{[30]}$. Around 116 million people had been benefited from the fishery sector and about $90 \%$ of them are working in the small-scale fisheries sector in the developing nations ${ }^{[31]}$. Fisheries output is dominated by capture fisheries and the total amount of fish production from aquaculture is increasing from time to time over the past decade in Africa. Fishery is one of the vital strategies for the poor to achieve food, income and other social benefits. For instance, it serves as an important source of diet for over one billion people ${ }^{[24]}$.

Ethiopia is a country with an area of $1,127,127 \mathrm{~km}^{2}$, water bodies cover approximately 7400 $\mathrm{km}^{2}{ }^{[12]}$. In Ethiopia, water bodies are a home of diverse aquatic life including more than 180 fish species of which about 40 are endemic ${ }^{[11]}$. Currently, the annual exploitable fish potential of Ethiopia is 51,481 tons ${ }^{[13,9,14]}$ of which only $24 \%$ is exploited right now. There are about 30 main lakes located in different environmental zones ranging from about 150 meters below sea level up to 4,000 meters above sea level ${ }^{[16]}$. In Ethiopia fish production rest on the inland waters for the quantity of fish as a low-priced source of animal protein. It can also indirectly add by providing income for purchasing food for undersupplied areas ${ }^{[17]}$. Ethiopia has a diverse environmental formations and climatic situations and it is endowed with considerable water resources and wetland ecologies, including river basins, major lakes, many swamps, floodplains and artificial reservoirs. The fish source in most cases comes from the major lakes and some reservoirs such as Abaya, Tana, Chamo, Hawasa, Langano, Gilgal gibe, Ficha, Ziway, Koka and rivers in the nation. The profits gained from the development of fisheries are substantial. From local to international levels, fisheries show important role in food supply, revenue generation, occupation creation and nourishment security ${ }^{[18]}$.

Nevertheless, the Ethiopian lakes are mainly experienced, are threatened by poor production system with catchment's deforestation (shore damage), water pollution and siltation, overfishing, habitat devastation, invasion of non-native species, illegal, and unregulated fishing ${ }^{[18,22]}$ and it is far below its potential ${ }^{[29]}$. 
Enhancements in fishery sector highly add to nourishing income of rural casting communal and ensure eco-friendly sustainability in Ethiopia.

In Oromia region, fishery shares $18.5 \%$ of the country's total fish production ${ }^{[10]}$. Langano Lake is found in oromia regional state rift valley and it has huge fish potential of 240 tonne/year and it is well known in Nile Tilapia, African Catfish, and Common Carp fish species ${ }^{[23]}$.

According to ${ }^{[9]}$, although there is some form of fisheries practiced in most freshwater bodies of Ethiopia, commercial fishery is concentrated at Lakes Tana, Chamo, Ziway, Abaya, Koka, Langano, Hawassa and Turkana. Similarly, [9] underscored that $40 \%$ and $50.2 \%$ of fish supply to the major urban centers in Ethiopia are captured from the Rift Valley lakes and Lake Tana. Despite the economic importance of fish farming at the household and national level, farm households have paid little attention to the sector in the study area (Langano Lake). In addition to this, fish farmers have not fully procured from the activity, which has huge potential to improve the living standards of their family. Even though fishery gives many advantages to the economy of the country, currently the participation of farm households' in fish production is poor in the study area. This needs research to answer the question why farm households do not participate in fish production. Answers to the aforementioned question give information for policy makers and professionals to strengthen the participation of farm households in fish production. Therefore, this study intends to find out the determinants of fish production in Lake Langano.

The general objective of the study is to identify the key determinants that affect the utilization of fishery resources, in pursuit of this, the following specific objectives were addressed:

1. To identify the determinants of fish production in lake langano

2. To investigate the challenges and opportunities of fishermen around lake langano

\subsection{The Main Research Question}

1. What are the key determinants that affect the utilization of fishery resources?

2. What are the determinants of fish production in the study area?

3. What are the challenges and opportunities of small scale fishermen operating in Lake Langano?

\section{Research Methodology \\ 2.1 Description of Study Area}

Langano Lake is found in the Arsi Nagele district of Oromia National Regional state of Ethiopia, at about 200 kilometers by road south of the capital, Addis Ababa. It is bordered between the East Shewa and West Arsi Zones of Oromia National Regional State. It is located to the east of Lake Abijata in the main Ethiopian rift valley at an elevation of 1585 meters. Fishing technologies such as fish drying using simple tent dryer, fish smoking technology and fish meal technology were verified and evaluated under Langano Lake condition. This study was undertaken in Arsi Nagele district of West arsi zone at Langano Lake. Lake Langano is 18 kilometers long and $16 \mathrm{~km}$ wide respectively, with a surface area of 225 square kilometers and a maximum depth of 46 meters. The average depth of Lake Langano were 12 meter. The fishery potential and fish catchment level of the lake langano were 240 tonne per one production year and 151 tons per year respectively ${ }^{[23]}$. The lake has a catchment 1600 square kilometers in size, and is drained by the Hora Kallo river which empties into the adjacent Lake Abijata ${ }^{[5]}$. Unlike all other freshwater lakes in Ethiopia, Lake Langano is popular with tourists and city-dwellers. The lake is brown in colour and at first sight one may think that the lake is not clean. However this is not the case, the reason for the brown color is due to the richness in minerals including high sulphur levels which have led many to believe that the lake water has healing properties. There are a number of resorts around the lake and water sports are popular. There are a variety of wild life around the lake, which include Hippos, monkeys, baboons, warthogs, and a huge variety of birds. The area around the lake is largely deforested, however, and a large number of herders live around the area.

\subsection{Sampling Method and Sample size Determination}

In this study, farmer household was the basic sampling unit. For this study, two-stage sampling technique was applied to draw representative sample respondents and generate primary data. In the first stage, two kebele (Langano hada mandiya, Kararu ido mandiya), which were nearest to the Langano Lake and has high potential in fish production were selected purposively. On the second stage, by stratifying the households into participants and non-participants, a probability proportional to sample size sampling procedure was employed to select 167 sample households from which 75 participants and 92 non-participants were randomly selected and used in the analysis, after preparing sample frame of participants and nonparticipants in the selected kebeles.

To determine the sample size from the study area, Cochran formula has been used ${ }^{[25]}$.

The sample size from each kebele was determined by proportionality formula. Therefore, the sample size is determined by the formula (1).

$\mathrm{n}=\frac{Z^{2} *(p)(q)}{d^{2}}$

n- Sample size

$\mathrm{Z}$ - Standard normal deviation (1.81 for $93 \%$ confidence level)

$\mathrm{p}=0.5$ (The proportion of the population participating in fish production, that is $50 \%$ due to unknown variability)

$\mathrm{q}=1-\mathrm{p}=0.5(50 \%)$

$\mathrm{d}$ - Desired degree of precision level, which is 0.07 in this case

Proportional sampling method has been used to select the sample from each of the five kebeles. The sample selected from each selected kebeles was proportional to the population in each kebele and the formula for this purpose was determined by the formula (2)

$\mathrm{n}_{\mathrm{i}}=\frac{\mathrm{N}_{\mathrm{i}(\mathrm{n})}}{\sum \mathrm{N}_{\mathrm{i}}} \ldots$

Where $\mathrm{n}_{\mathrm{i}}-$ the sample to be selected from i`s kebele $N i$ - the total population living in the selected i`s kebele $\sum$ - the summation sign $\sum N i$ - the sum of the total population in the selected five kebeles $n$ - Total sample size 


\subsection{Data Types, Data Sources, and Methods of Data Collection}

Both secondary and primary data were collected for this study. The sources for secondary data are local offices, higher governmental organizations, different publications and policy documents whereas the primary data were collected from the sample farmers using face to face interview. To obtain primary data, semi-structured questionnaire, with closed and Open-ended questions was used as a tool to collect data from sample households. For conducting this study, important variables on economic, social and institutional factors related to the households in the study area were collected. Key informants and focus group discussion interviews, unstructured interview (guiding question) was used as a tool of data collection.

\subsection{Methods of Data Analysis 2.4.1 Descriptive Statistics}

Descriptive statistics were used to explain the different characteristics of the households in the study area. The descriptive statistics such as minimum, maximum, standard deviation and mean were used for these analyses. Statistical significance of the variables was used for both dummy and continuous variables using chi-square $\left(\mathrm{x}^{2}\right)$ and student t-test statistics, respectively by using Stata version 13 software.

\subsubsection{Econometric Model Specification}

In this study, the participation decision of the farmers in fish production practice is the dependent variable. Household's participation decision in fish production is dichotomous (binary), it takes a value of 1 if the household has participated in fish production practices and zero otherwise. Since, the scope of this study is only the participation decision of the farmers, it is possible to use either binary logit or binary probit model. As indicated in ${ }^{[26]}$, logit or probit models are widely applied to the analysis of determinant studies for a limited dependent variable and their result is similar. Contrary to this, ${ }^{[27]}$ suggests that although both models result with similar outputs, the logit model is easier in the estimation, even though this is not the problem nowadays since it is the work of the computer software within a couple of seconds. These two models are used only for the analysis of the probability of participation in a particular technology. Both are only suited in determining the probability models but not for linear models. Probit is used in estimating the factors determining the probability of participation in fish production.
2.4.1.1 Participation Decision Equation is specified as Follows

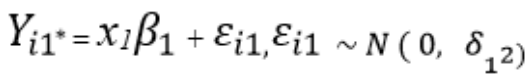

$\cdots$

$Y_{i 1}=\left\{\begin{array}{l}1, \text { if } Y_{i 1^{*}}>0 \\ 0, \text { if } Y_{i 1^{*}} \leq 0\end{array}\right.$

Where $Y_{i 1}$ is unobserved (latent) variable for the participation decision in fish production, $Y_{\text {i1 }}$ is the observed discrete decision of the farmer whether he/she has participated or not in fish production, the subscript $\mathrm{i}$ refers to the $\mathrm{i}^{\text {th }}$ household, the subscripts 1 refer to the variable related to the participation equation.

$X_{I}$ 's are the index of explanatory variables determining the participation decision of the farmers in fish production practice, $\beta_{1}$ refers to the index of parameters related to explanatory variables determining participation decision of the farmer, $\varepsilon_{i 1}$ is the error term of the participation equation which is distributed $\left(\varepsilon_{i 1} \sim N\left(0, \delta_{I}^{2}\right)\right)$, with mean and constant variance.

\subsubsection{Analysis of the Marginal Effects of Participation Decision}

The marginal effects that are determined from the estimation of probit part of double hurdle model in this particular study interest could be determined by using the formula of partial derivations/ partial effects based on ${ }^{[28]}$.

The marginal effect, the effect of a unit change or discrete change in explanatory variables on the probability of participating in fish production can be given as follows.

$$
\frac{\partial P\left(Y_{\left.i 1=1 / X_{i}\right)}\right.}{\partial X_{j}}=\beta_{j} \emptyset(X \beta)
$$

Where $\beta_{j}$ is the coefficient on $x_{j}$ and $\emptyset(x \beta)$ is the standard normal probability density function which would be evaluated at $\left(\beta_{0}+\beta_{1} X_{1}+\beta_{2} X_{2+\cdots}\right)$.

For the continuous explanatory variables, these marginal effects are used to calculate elasticity at the sample means because the slope of the dependent variable is not constant at different per unit change of the variables. For the discrete or categorical variables, the marginal effects are used to calculate percentage changes in the dependent variable when the variable shifts from zero to one, ceteris paribus.

Table 1: Definition and description of the working dependent and explanatory variables

\begin{tabular}{|c|c|c|}
\hline \multicolumn{2}{|c|}{ Variables } & Measurement \\
\hline \multicolumn{2}{|c|}{ Dependent variables } \\
\hline Farmers participation decision in fish production & For participant, 0 otherwise & \\
\hline \multicolumn{2}{|c|}{ Independent variables } \\
\hline Fishing Experience & year & + \\
\hline Access to the fishing equipment & 1 for yes, 0 otherwise & - \\
\hline Distance of household home from lake & Kilometer & + \\
\hline Access to the extension services & 1 for yes, 0 otherwise & + \\
\hline Access to the modern transportation services & 1 for yes, 0 otherwise & + \\
\hline Access to the credit service & 1 for yes, 0 otherwise & + \\
\hline Size of household & Man equivalent & + \\
\hline Household head education level & year of schooling & + \\
\hline Access to the market information & 1 for yes, 0 otherwise & \\
\hline Sex of household head & 1 for male, 0 otherwise & \\
\hline
\end{tabular}


Both literature review and theoretical review were undertaken to select potential explanatory variables which could affect the participation decision of farmer's participation in fish production. The impact of independent variables on the participation decision of farmer in fish production were hypothesized based on the information obtained from a literature and theoretical review of previous work ${ }^{[15,20]}$.

\section{Results and Discussion}

This section of the paper is devoted to present and discuss the basic outputs of the research. Here the details of the findings about the determinants of the participation in fishing have been discussed below.

\subsection{Descriptive Analysis}

In this section, descriptive statistics of the pre-treatment and socio-economic, environmental, institutional and demographic characteristics of the sample households that are hypothesized to affect participation in modern beekeeping included in the model are presented. These variables are selected based on economic theory, previous empirical studies and information collected during the survey.

The distribution of the categorical variables related to fishing practice participants and non-participants is given in Table 1. The proportion of the respondents falling into these categories is given and the difference of the proportion across non-participants and participants were tested by using chisquare test. The summary of continuous variables related to the fish production participants and nonparticipants along with their mean difference test (t-test) is given in table 2. After estimating the mean values, the significance of the mean difference test was undertaken by two-group mean comparison test for the continuous variables. The detailed discussion of both categorical and continuous variables is presented under different conceptual groups.

Table 1: Distribution of the categorical variables across fishing farmers and non-fishing farmers

\begin{tabular}{|c|c|c|c|c|c|}
\hline \multicolumn{3}{|c|}{ Observation $=167$} & Fisher men $=75$ & Non-fisher men $=92$ & \multirow{2}{*}{$\begin{array}{c}\mathrm{Chi}^{2} \\
\text { value }\end{array}$} \\
\hline Explanatory variables & & Frequency (Proportion/\%) & Frequency (Proportion/\%) & Frequency (Proportion/\%) in \%) & \\
\hline \multirow{2}{*}{ Fish equipment } & Access & $83(49.70)$ & $55(73.33)$ & $28(30.43)$ & \multirow{2}{*}{$15.35 * * *$} \\
\hline & No access & $84(50.30)$ & $20(26.67)$ & $64(69.57)$ & \\
\hline \multirow{2}{*}{ Credit } & Access & $94(56.29)$ & $40(53.33)$ & $54(58.70)$ & \multirow{2}{*}{0.75} \\
\hline & No access & $73(43.71)$ & $35(46.67)$ & $38(41.30)$ & \\
\hline \multirow{2}{*}{ Extension } & Access & $106(63.47)$ & $58(77.33)$ & $48(52.17)$ & \multirow{2}{*}{$13.13 * * *$} \\
\hline & No access & $61(36.53)$ & $17(22.67)$ & $44(47.83)$ & \\
\hline \multirow{2}{*}{ Transportation } & Access & $81(48.50)$ & $36(48.00)$ & $45(48.91)$ & \multirow{2}{*}{$9.19 * * *$} \\
\hline & No-access & $86(51.50)$ & $39(52.00)$ & $47(51.09)$ & \\
\hline \multirow{2}{*}{ Sex } & Male & $141(84.43)$ & $70(93.33)$ & $71(77.17)$ & \multirow{2}{*}{$1.76^{*}$} \\
\hline & Female & $26(15.57)$ & $5(6.67)$ & $21(22.83)$ & \\
\hline \multirow{2}{*}{ Mkt information } & Access & $93(55.69)$ & 71 (94.67) & $22(23.91)$ & \multirow{2}{*}{$18.83 * * *$} \\
\hline & No access & $74(44.31)$ & $4(5.33)$ & $70(76.09)$ & \\
\hline
\end{tabular}

* And *** shows significant at $10 \%$ and $1 \%$ level of significance

Source: Own computation result from survey data, 2019

\section{Access to the modern fishing equipment}

This variable is also analyzed across fisher men and nonfishermen in fishing practice in the study area. For the total observation, $50.30 \%$ of households do not have modern fishing equipment access, whereas $26.67 \%$ of the participant and $69.57 \%$ of nonparticipants have no access to modern fishing equipment access. The chi-square value indicates that there was a significant difference between fishing farmers and non-fishing farmers on the accessibility of modern fishing equipment at $1 \%$ level of significance.

Credit access: This variable is analyzed across fishing farmers and non-fishing farmers. For the total sampled households, about $43.71 \%$ did not use credit, whereas the proportion of those did not use credit are $41.30 \%$ for nonparticipants and $46.67 \%$ for participants. Chi-square test indicated that there was no significant difference between participants and nonparticipants.

Access to the extension services: For the total observation about $36.53 \%$ of households did not obtain extension services on the fish production practices. About $47.83 \%$ of the nonfishers and $22.67 \%$ of the fishers had not obtained access to extension services on the fish production issues. There was a significant difference between the participants and nonparticipants in terms of accessibility of extension services at $1 \%$ significance level. The result of this variable indicates that the fish production participant households had obtained extension services on the fishing issues more than the nonparticipant households.

\section{Access to the transportation services}

The proportion of households that do not have access to the transportation service was about $51.50 \%$ for the total sampled households. The proportion of households that have access to transportation service for non-fishing farmers was about $48.91 \%$ whereas that of fishing farmers was about $48.00 \%$ and the chi-square value of the proportionality test for this variable indicates that there was significant difference between fishing farmers and non-fishing farmers in the fishing practice at $1 \%$ significance level.

\section{Sex of household head}

For the total observation, $84.43 \%$ of the sample households were male-headed, whereas $15.57 \%$ of households were female-headed. About $93.33 \%$ and $77.17 \%$ of male-headed households were participants and nonparticipants respectively. Female-headed households were $6.67 \%$ participants and $22.83 \%$ nonparticipants (Table 1). There was a highly significant difference between participants and nonparticipants in terms of the sex of households' at $10 \%$ significance level. The result of this variable indicated that male-headed households participate more in fish production practices than female-headed households.

\section{Access to the market information}


For the total observation about $44.31 \%$ of households did not obtain market information access on the fishing practice. About $76.09 \%$ of the non-participants and $5.33 \%$ of the participants had not market information access on the fishing practices while $94.67 \%$ of the participants were obtained market information access on the fish production issues
(Table 1). There was a significant difference between the participants and nonparticipants in terms of access to the fish product marketing information at $1 \%$ significance level. The result of this variable indicates that the fishermen households had obtained market information on the fishing issues more than the nonparticipant households.

Table 2: Summary statistics of continuous variables

\begin{tabular}{|c|c|c|c|c|c|c|c|c|c|c|c|c|c|c|}
\hline \multicolumn{4}{|c|}{ For the total Observation =167 } & \multicolumn{4}{|c|}{ Participants=75 } & \multicolumn{3}{c|}{ Non-participants=92 } & \multirow{2}{*}{ Mean diff. test (t value) } \\
\hline Variable & Mean & Std. Dev & Min & Max & Mean & Std. Dev & Min & Max & Mean & Std. Dev & Min & Max & \\
\hline Education & 7.81 & 3.50 & 0 & 13 & 8.94 & 3.11 & 1 & 13 & 6.89 & 3.56 & 0 & 13 & $4.458^{* * * *}$ \\
\hline Experience & 7.10 & 6.47 & 0 & 27 & 8.82 & 7.60 & 1 & 27 & 5.6 & 4.99 & 0 & 21 & $3.14 * * *$ \\
\hline Lake distance & 15.07 & 9.38 & 3 & 28 & 8.78 & 5.11 & 3 & 28 & 20.19 & 8.95 & 3.7 & 28 & $-5.40^{* * *}$ \\
\hline Household size & 6.05 & 3.16 & 2 & 13 & 5.36 & 3.08 & 2 & 13 & 6.62 & 3.11 & 2 & 13 & 0.4332 \\
\hline
\end{tabular}

Education level of household head (Education): The mean education of the total households in the study area was 7.81 in terms of years of schooling, whereas the non-participants and participants had a mean education level of 6.89 and 8.94 years of schooling, respectively (Table 2). There was a significant difference in the education level between participants and non-participants household heads at $1 \%$ level of significance. The result indicates that the education level of the nonparticipants was lower as compared to the participants education level.

Experience of fish production practices: The mean fish production experience of the total households in the study area was 7.08 years, with minimum and maximum experience of 0 and 27 years, respectively with the standard deviation of 6.48 year. But the mean fish production experience of the non-participants was 5.6 with the minimum and maximum experience of 0 and 21 respectively and standard deviation of 4.99, whereas that of the participants was 8.8, 1 and 27 respectively with a standard deviation of 7.64 (Table 2). The descriptive analysis revealed that there was a significant difference in the year of experience of households between participants and non-participants in the fish production practice. The mean difference of fish production experience between the non-participants and participants was highly significant at $1 \%$ level of significance. This implies that the experience of the participants was higher as compared to nonparticipants. Someone may assume that the fishing practices experience of non-participants would be zero, but in this particular case of study, the experience of non-participants on average was different from zero because they were participating in the fish production practice some years ago, but not practicing currently. This indicates that there was dis adoption in fish production and it is one problem observed in the study area which needs further analysis for the reason behind dis-adoption by researchers in the future.
Distance of household home from Lake Langano: It is used in the analysis of the characteristics of the farm household in the study area. The mean distance of the household's home from the lake langano for the total households in the study area was found to be $15.07 \mathrm{~km}$, while the mean figures are $8.78 \mathrm{~km}$ and $8.95 \mathrm{~km}$, concerning the distance of the household's home from the lake langano for participants and nonparticipants respectively. The minimum and maximum distance of household's home from the lake langano for the participants was $3 \mathrm{~km}$ and $28 \mathrm{~km}$ respectively, whereas that of the nonparticipant was $3.7 \mathrm{~km}$ and $28 \mathrm{~km}$ respectively. There was a significant difference in the home distance of households between fishers and non-fishers at $1 \%$ level of significance. The result of the analysis shows that the distance of the household's home from the lake for the participants was lower as compared to the non-participants.

Household size: The mean household size of the total sample households in the study area were about 6 adult equivalent with minimum and maximum household size of 2 and 13 respectively. The mean household size of participants was 5.36 with minimum and maximum household size of 2 and 13 adult equivalent respectively, and that of nonparticipants was 6.62 adult equivalent, with minimum and maximum household size of 2 and 13 adult equivalent respectively. The descriptive analysis revealed there was no a significant difference in the household size of household heads between participants and nonparticipants in the fishing practices.

\subsection{Econometric Analysis}

Factors Determining Participation Decision in Fish Production: The result from the probit model revealed that out of the ten explanatory variables included in the model, five of them were found significantly determined the participation decision of the farmers in fish production at the different level of significance and in the different directions.

Table 3: Determinants of participation in fish production in the study area

\begin{tabular}{|c|c|c|c|c|}
\hline Variables & Coefficient & Robust Std. Err. & $\mathbf{Z}$ & Marginal Effect \\
\hline Modern transportation access & $0.3124^{* *}$ & 0.1517 & 2.06 & 0.1223 \\
\hline Credit access & -0.3097 & 0.2427 & -1.28 & -0.1202 \\
\hline Education & $3.01^{*}$ & 1.35 & 2.23 & 0.7011 \\
\hline Experience & 0.0387 & 0.0292 & 1.32 & 0.0151 \\
\hline Extension access & $0.4877^{*}$ & 0.2404 & 2.03 & 0.1860 \\
\hline Lake distance & -0.0117 & 0.0244 & -0.48 & -0.0045 \\
\hline Household size & $0.0571^{*}$ & 0.0272 & 2.10 & 0.0223 \\
\hline Market information access & 0.1424 & 0.2729 & 0.52 & 0.0554 \\
\hline Sex & $0.9373^{*}$ & 0.5137 & 1.82 & 0.3530 \\
\hline Fishing equipment access & 0.1806 & 0.4094 & 0.44 & 0.0703 \\
\hline Constant & -0.4778 & 0.8830 & -0.54 & \\
\hline Observation number $=167$ & & & & \\
\hline
\end{tabular}




\begin{tabular}{|c|c|}
\hline \multicolumn{3}{|c|}{ Wald chi2 $(10)=63.14$} \\
\hline Log pseudo likelihood $=-78.637275$ & Prob $>$ chi2 $=0.0000$ \\
\hline$*$ and $*$ *indicates significant at $10 \%$ and $5 \%$ level of significance respectively \\
\hline
\end{tabular}

Source: Own computation result from survey data, 2019

Access to the extension services (Extension): This variable was found significant at a 5\% significance level and positively related to the household participation decision in fishing practices. The result of the marginal effect of this variable, 0.1860 reveals that the predicted probability of participating in fishing practices increases by $18.60 \%$ for the farmers having access to the extension services as compared to the farmers who do not have access to the extension services. The possible reason for this result may be the farmers who have got access to extension services about the capture fishing issues to tend to be more progressive and more aware about the fish production and more likely to experiment with fishing practice. They provide training to improve the technical skills of farm households to improve their fish production and productivity. This act triggers non-participants to engage in fish production. This finding was similar to the finding of ${ }^{[1,8]}$.

Access to the modern transportation service: It had a positive and statistically significant effect on the farmer's participation in fish production. The model result indicated that the probability of participating in fish production increases by $12.23 \%$ if the head gets access to modern transportation service. Modern transport improves the quality of fish product by minimizing the perishability of the product and facilitates the interaction between surplus and deficit geographical areas. This indicates that transportation service is a crucial factor to create a market for fish production which improves the living standards of the households. According to [2], fish is the most perishable food item especially in the tropical climates of developing countries. Therefore, modern transportation service is a viable solution to minimize the degree of perishability. Similarly, most of the fish catch from the lakes reach the market by traditional means of transportation which causes mechanical stress to fish products [9]. This entails that modern transport service enables farm households to supply raw and processed fish in different areas where fish products have higher demand. This helps them to receive a better price for their product and increase their benefit from their product which leads to the improved living standard of their household members. The discussion by [3] reported that fish is one of the most perishable of human food item, which starts spoiling soon after death. The perishability nature of fish after death and lack of modern transport service heavily hamper the participation of farm households in fish production. Therefore, effective transportation service coupled with value addition activities minimizes the spoilage of fish after death. This entails that modern transport services increase farm households' participation in fish production.

Household head education level (Education): Educational status had a positive and statistically significant effect on the farmer's participation in fish production at the $5 \%$ significance level. The probability of participating in fish production increases by $70.11 \%$ if the household head is educated. This implies that the participation of educated households in fish production is more than illiterate households head. This is because educated heads have better knowledge about the role of fish production to diversify household income so as to achieve food security of his/her family than un educate household heads. In addition to this, education is an important tools to change the lives of smallholder farmers because educated household heads adopt important technologies and manipulate these technologies easily to improve their production and productivity which gives them more chance to engage in other alternative farm and non-farm activities. For example, ${ }^{[4]}[6]$ examined the relationship between educational status and its influence on fish production and found that educational status had a significant influence on fish production at less than 5\% significance level, which is in line with the finding of this study.

Household size: As expected, this variable had a positive and statistically significant effect on households' participation in fish production. The model result revealed that the probability of participating in fish production increases by $2.23 \%$ for a unit increase in household size. This relationship indicates that large household size increases the households' participation in fish production. This is because having a large household size requires more food and income to satisfy their basic needs. In the study area, fish production is the dominant income and food source. As a result, the household head who has a large household size has participated in different fish production and processing activities to full fill the basic needs of his/her household members. The result of this study is the same with previous studies ${ }^{[11]}$.

Sex of household head (Sex): Sex of the respondents was hypothesized that it has a positive influence on the participation decision of the farmers in fish production. The result of the binary probit model has shown that, as expected sex has positively influence on the farmers' participation decision in fishing at $10 \%$ significant level. Odds ratio suggested keeping the other variable remain constant, being a male can increase the probability of participating in fishing activities by the factor of 0.3530 . This confirm that male headed household is more likely to participate in fishing than female headed household. This indicates that, it is challenging for females on manipulating all labor intensive fishing gear on the lake during harvesting time. The finding is in line with many previous research finding that fishing is mainly undertaken by male households $[5,6,19,21]$.

\subsection{Constraints and Opportunities of Fishing activities in the study area \\ 3.3.1 Constraints of Fish Production in Lake Langano}

As indicated in the Table 4 below, $29.94 \%$ of respondents ranked high overfishing, that means, with growing populations, there is a need to feed more and more people. Coupled with effective open-access systems, this often translates into increasing pressure on resources, and many fish stocks are now overfished. This reduces productivity, resulting in fewer fish being available and at higher prices as the first major constraint, and $19.76 \%$ of respondents ranked poor management practices, knowledge, and skill of farmers about the fishing activities as the second major constraint in the study area. About $17 \%$ of respondents ranked problem of 
climate change, wetland degradation, in efficient fishing gears and fish disease as the third major constraints. The fourth, fifth, sixth and seventh major fish production constraints were poor transportation services, low price at the landing site, lack of modernized fishing training and boat services, and poor extension services respectively.

Table 4: Major constraints of modern beekeeping practice in the study area

\begin{tabular}{|c|c|c|c|}
\hline Major Constraints & Frequency & Percentage $(\%)$ & Rank \\
\hline Overfishing problem & 50 & 29.94 & $1^{\mathrm{st}}$ \\
\hline Poor management practices, knowledge, and skill of fishermen & 33 & 19.76 & $2^{\text {nd }}$ \\
\hline Problems of climate change and fish disease & 28 & 16.76 & $3^{\text {rd }}$ \\
\hline Poor transportation access & 23 & 13.77 & $4^{\text {th }}$ \\
\hline Low price problem at landing site & 16 & 9.58 & $5^{\text {th }}$ \\
\hline lack of modern fishing training & 10 & 5.99 & $6^{\text {th }}$ \\
\hline Poor extension services & 7 & 4.2 & $7^{\text {th }}$ \\
\hline Total & 167 & 100.00 & \\
\hline
\end{tabular}

Source: own estimation from the survey data, 2019

\subsubsection{Opportunities of Fish Production in Lake Langano}

According to the respondent response, the major opportunities for fish production in the study area include creation of job opportunities for the youth $(25.15 \%)$, Oromia saving and credit institute open its branch in Arsi Nagele town. One cooperative out of the six cooperative starts to save some amounts of money monthly; this may give some insight to the fishers to become economically more influential. Likewise, the presence of fishery proclamation contributes to ban illegal fishing instruments and protect the fishery (19.76\%), Presence of different resort, fish cooperative and international and domestic tourists in the area $(17.36 \%)$, presence of Batu fish and other aquatic life research center at Batu town, which mainly support fishery development sector within which fishing activities are is encouraged (14.97\%), indigenous knowledge of the farmers about the fishing activities $(13.17 \%)$, and increased fish product demand by international and domestic tourists $(9.6 \%)$ in the study area.

Therefore, if the government, nongovernment organizations and beneficiaries give more support in terms of modern beekeeping development, the study area would be more beneficial for its society as well as feeding the other areas and contributing to the economic development of the country.

\section{Conclusion and Recommendation}

This study examined factors affecting farm households' participation in fish production of Langano Lake. Descriptive statistics result indicated that there is a strong and significant mean difference among fishermen and non-fishermen respondents as indicated by the most of the explanatory variables included in the probit model. Probit model result showed that Access to the extension services, Access to the modern transportation service, Household head education level, Household size and Sex of household head has a statistically significant effect on the farmer's participation decision in fish activities. In the Langano lake fishing activities are practiced at different landing sites both by individual fisherman and fishermen cooperatives; however, the activity is practiced by in traditional form and did not aid by modernized technology due to various problems like poor implementation of policies and regulations, irresponsible fishing activities, poor coordination and management of the lake, other resources and stakeholders, lack of fishing facilities and infrastructures and lack of fishing training.

Based on the findings of the current study and relating to the previous works, the following recommendations were forwarded.

- Enforcement of management measures, effective training and extension work should be implemented which incorporate active participation of the fisher community including the so called illegal fishers. Moreover, continues support for organized fishery cooperatives should be done in terms of finance and training.

- Monitoring of the common fish species which are presented in the lake and other fishes in and around Lake Langano need to be strengthened for conservation as well as production purposes

- Lake Langano is open to anyone who wishes to join the fishing business and this leads to the over-exploitation of the resources. Hence, rights and responsibilities should be specified on fishing communities to restore, protect and manage local aquatic and coastal ecosystems on which they depend for their well-being and that they have used for their livelihoods.

- Since the technical knowledge of the fishers in the study area is very poor. Training institutions, agencies and developmental partners must collaborate with the government to provide training and extension services to fish farmers to improve their knowledge in fish production practices.

- Government participation in fish farming in the area is important; policies that would facilitate provision of credit to the fish farmers as well as increase the number of contact of the fish farmers with extension personnel should be made to boost the quantity of fish available for consumption.

- Fish farming in the area is dominated by males; females should be encouraged to participate in fish farming as a means of augmenting their income.

\section{Acknowledgement}

I would like to express my sincere gratitude to Oromia Agricultural research Institute and Haramaya University Climate Change and Smart agriculture project for funding the research work. I would also like to express my honest gratitude to my Advisor Dr. Abule Mehari (PhD) for his valuable time, thoughtful and constructive comments, professional advice and all invaluable guidance for this research paper.

\section{References}

1. Birara E, Melese Z, Workneh Y, Zemen A. Determinants of farm households' participation in fish production in Southwest Ethiopia. Cogent Food and Agriculture 2020;6(1):1728107.

2. Kumolu Johnson C, Ndimele P. A review on post-harvest losses in Artisanal fisheries of some African countries. 
Journal of Fisheries and Aquatic Science 2011;6:365-3. doi:10.3923/jfas.2011.365.378.

3. Asmah R. Development potential and financial viability of fish farming in Ghana. Scotland: Inistitute of Aquaculture University of Stirling. 2008. Retrieved from https://dspace.stir.ac.uk/bitstream/1893/461/1/PhD\% 20Document.pdf

4. Muchangi CT. Influence of farmer's characteristics, agricultural extension and technology specific factors on adoption of organic farming technologies in Embu West Sub County, Embu, Kenya. PhD. Thesis, University of Nairobi, Embu, Kenya, 2016.

5. Askale GM, Tegegn F. Assessment of the fishery, challenges and opportunities of Denbi reservoir in Bench Maji Zone, South Western part of Ethiopia. International Journal of Fisheries and Aquaculture 2018;11(1):7-12.

6. Assefa M, Lemma Z. Fishermen's willingness to pay for fisheries management: The case of Lake Ziway, Ethiopia. International Journal of Fishery and Aquatic Science 2015;2(6):320-325.

7. CSA. National Statistics 2005.

8. Njagi KA, Njati IC, Huka G. Factors affecting profitability of fish farming under economic stimulus program me in Tigania East District, Meru County, Kenya. IOSR Journal of Business and Management 2013;15:25-36. Doi: 10.9790/487X-1532536

9. Lemma AH. Fisheries production system scenario in Ethiopia. International Journal of Fisheries and Aquatic Studies 2017;5:79-84.

10. Assefa M. Assessment of fish products demand in some water bodies of Oromia, Ethiopia: International Journal of Agricultural Sciences 2013;3(8):628-632.

11. Birhanu W. Determinants of fish production in Lake Ziw ay. Ethiopia. St. Mary University. 2015. Retrieved from h ttp://repository.smuc.edu.et/bitstream/ 123456789/2484/1 /Wubeshet\%20Birhanu.pdf.

12. Cheffo A. Teshome H, Tesfaye G. Opportunities and challenges of fish marketing at Gelgel Gibe Dam in Ethiopia 2015. St.Mary University. Retrieved from http://197.156.93.91/bitstream/ 123456789/2668/1/Abebe \%20Cheffo\%20Revised\% 2015\%20April\%202016.pdf.

13. Chekol A. Management and livelihood opportunity of Lake Tana Fishery. Ethiopia: the need for co management. Norwegian College of Fisheries Science, the Arctic University of Norway. 2013. Retrieved from https://munin.uit. no/bitstream/hand le/10037/5916/thesis.pdf? Sequence $=1$

14. Meko T, Kebede A, Hussein A. Tamiru Y. Review on opportunities and constraints of fishery in Ethiopia. International Journal of Poultry and Fisheries Sciences 2016;1:1-8.

15. George F, Olaoye O, Akande O, Oghobase R. Determinants of aquaculture fish seed production and development in Ogun State, Nigeria. Journal of Sustainable Development in Africa 2010;12:22-34.

16. Dejen E, Mintesnot Z. A generic GIS based site suitability analysis for pond production of Nile Tilapia (Oreochromis niloticus) in Ethiopia. In The Fourth Annual Conference of the Ethiopian Fisheries and Aquatic Sciences Association. Addis Ababa, Ethiopia: EFASA 2012.

17. Dawit G, Asefa A, Gezahegn A, Fekadu B. Analysis of the significance of fishing on food security status of rural households around Lakes Ziway and Langano in
Ethiopia. J. Econ. Sustainable Development 2013;4:1-10.

18. Hecky RE, Mugidde R, Ramlal PS, Talbot MR, Kling GW. Multiple stressors cause rapid ecosystem change in Lake Victoria. Freshwater Biolology 2010;55:19-42.

19. Ojulu CG. Determinants of volume of fish production in fisheries cooperatives in Abobo district southern Gambella regional state, Ethiopia. International Journal of Arts and Science Research 2017;4(1):18-28.

20. Ofuoku A, Olele N, Emah G. Determinants of adoption of improved fish production technologies among fish farmers in Delta State, Nigeria. Journal of Agricultural education and Extension 2008;14:297-306. Doi: 10.1080/13892240802416186

21. Bikila K, Amanuel Z. Socio-Economic and Profitability of Fisheries Enterprises the Case of Fincha Amarti Nashe Reservoir of Oromia State, Horo Guduru Wollega zone, Ethiopia. Industrial Engineering Letters 2016;6(9):32-45.

22. Dereje T. Spatial and temporal distributions and some biological aspects of commercially important fish species of Lake Tana, Ethiopia, Coastal Life Med 2014;2(8):5.

23. Assefa MJ. Fish Production, Consumption and Management in Ethiopia. Research Journal of Agriculture and Environmental Management 2014;3(9):460-466.

24. Manasi S, Latha N, Raju KV. Fisheries and livelihoods in Tungabhadra Basin, India: Current status and future possibilities. Working Paper, the Institute for Social and Economic Change, Bangalore 2009, 24.

25. Cochran WG. Sampling Techniques 3rd Edition, New York: John Wiley and Sons, Inc 1977.

26. Gujarati DN. Basic Econometrics, McGraw-Hill International Editions, (3rd Edition). 1995.

27. Green W. Econometric Analysis 5th edition. Prentice Hall. Inc, New York 2003.

28. Heckman J. Sample selection bias as a specification error. Econometric 1979;47:153-161.

29. Kebede A, Meko T, Hussein A, Tamiru Y. Review on Opportunities and Constraints of Fishery in Ethiopia. International Journal Poultry Fish Science 2017;1(1):1-8.

30. Olale E. and Henson S. The impact of income diversification among fishing communities in Western Kenya. Food Policy report 2013;43:90-99.

31. WB (World Bank).The Hidden Harvests the Global Contribution of Capture Fisheries: Agriculture and Rural Development Department-Sustainable Development Network; the FAO and the World Fish Center: Washington, DC, USA 2010. 